\title{
Generalized distances and their associate metrics. Impact on fixed point theory
}

VASile Berinde and Mitrofan CHOBAN

\section{ABSTRACT.}

In the last years there is an abundance of fixed point theorems in literature, most of them established in various generalized metric spaces. Amongst the generalized spaces considered in those papers, we may find: cone metric spaces, quasimetric spaces (or $b$-metric spaces), partial metric spaces, $G$-metric spaces etc. In some recent papers [Haghi, R. H., Rezapour, Sh. and Shahzad, N., Some fixed point generalizations are not real generalizations, Nonlinear Anal., 74 (2011), 1799-1803], [Haghi, R. H., Rezapour, Sh. and Shahzad, N., Be careful on partial metric fixed point results, Topology Appl., 160 (2013), 450-454], [Samet, B., Vetro, C. and Vetro, F., Remarks on G-Metric Spaces, Int. J. Anal., Volume 2013, Article ID 917158, 6 pages http://dx.doi.org/10.1155/2013/917158], the authors pointed out that some of the fixed point theorems transposed from metric spaces to cone metric spaces, partial metric spaces or $G$-metric spaces, respectively, are sometimes not real generalizations. The main aim of the present note is to inspect what happens in this respect with $b$-metric spaces.

Acknowledgements. The first author's research was supported by the Grant PN-II-RU-TE-2011-3-239 of the Romanian Ministry of Education and Research.

\section{REFERENCES}

[1] Agarwal, R. P. and Karapinar, E., Remarks on some coupled fixed point theorems in G-metric spaces, Fixed Point Theory Appl., 2013, 2013:2

[2] Arhangel'skii, A. V., Mappings and spaces, Uspehi Mat. Nauk 21, No. 4 (130) 133-184 (Russian); translated as Russian Math. Surveys, 21 (1966), No. $4,115-162$

[3] Bakhtin, I. A., The contraction mapping principle in almost metric spaces, Functional Anal., Ulianowskii Gos. Ped. Inst., 30 (1989), $26-37$

[4] Berinde, V., Approximation of Fixed Points, Springer, Berlin Heidelberg New York, 2007

[5] Berinde, V., Generalized contractions in quasimetric spaces, Seminar on Fixed Point Theory, Preprint No. 3 (1993), 3-9

[6] Berinde, V. and Choban, M. M., Generalized metrics and their associate metrics. Relevance in metrical fixed point theory, Creat. Math. Inform., 22 (2013), No. 1, 11-18

[7] Boriceanu, M., Fixed point theory for multivalued contractions on a set with two b-metrics, Creat. Math. Inform., 17 (2008), No. 3, 326-332

[8] Cegielski, A., Iterative methods for fixed point problems in Hilbert spaces, Lecture Notes in Mathematics, Vol. 2057, Springer, Heidelberg, 2012

[9] Chidume, C., Geometric Properties of Banach Spaces and Nonlinear Iteration, Lecture Notes in Mathematics, Springer, 2009

[10] Chittenden, E. W., On the equivalence of écart and voisinage, Trans. Amer. Math. Soc., 18 (1917), 161-166

[11] Choban, M. M. and Calmuţchi, L. I., Fixed points theorems in multi-metric spaces, Ann. Acad. Rom. Sci. Ser. Math. Appl., 3 (2011), No. 1, 46-68

[12] Choban, M. M. and Calmuţchi, L. I., Fixed point theorems in E-metric spaces, ROMAI J., 6 (2010), No. 2, $83-91$

[13] Czerwik, S., Nonlinear set-valued contraction mappings in B-metric spaces, Atti Sem. Mat. Univ. Modena, 46 (1998), $263-276$

[14] Engelking, R., General Topology, Warszawa: PWN, 1977

[15] Fréchet, M., Les espaces abstraits, Gauthier-Villars, Paris, 1928

[16] Frink, A. H., Distance functions and the metrization problem, Bull. Amer. Math. Soc., 48 (1937), 133-142

[17] Haghi, R. H., Rezapour, Sh. and Shahzad, N., Some fixed point generalizations are not real generalizations, Nonlinear Anal., 74 (2011) 1799-1803

[18] Haghi, R. H., Rezapour, Sh. and Shahzad, N., Be careful on partial metric fixed point results, Topology Appl., 160 (2013) $450-454$

[19] Kada, O., Suzuki, T. and Takahashi, W., Nonconvex minimization theorems and fixed point theorems in complete metric spaces, Math. Japon., 44 (1996), 381-391

[20] Nedev, S. and Choban, M., On the theory of o-metrizable spaces. I, (Russian) Vestnik Moskov. Univ. Ser. I Mat. Meh., 27 (1972), No. 1, 8-15

[21] Nedev, S. and Choban, M., On the theory of o-metrizable spaces. II (Russian) Vestnik Moskov. Univ. Ser. I Mat. Meh., 27 (1972), No. 2, 10-17

[22] Nedev, S. and Choban, M., On the theory of o-metrizable spaces. III (Russian) Vestnik Moskov. Univ. Ser. I Mat. Meh., 27 (1972), No. 3, 10-15

[23] Rus, I. A., Generalized Contractions and Applications, Cluj University Press, Cluj-Napoca, 2001

[24] Rus, I. A., Petruşel, A. and Petruşel, G., Fixed Point Theory, Cluj University Press, Cluj-Napoca, 2008

[25] Suzuki, T., Generalized distance and existence theorems in complete metric spaces, J. Math. Anal. Appl., 253 (2001), No. 2, 440-458

[26] Tataru, D., Viscosity solutions of Hamilton-Jacobi equations with unbounded nonlinear terms, J. Math. Anal. Appl., 163 (1992), No. 2, 345-392

[27] Aage, C. T. and Salunke, J. N., Fixed points for weak contractions in G-metric spaces, Appl. Math., E-Notes, 12 (2012), $23-28$

[28] Abbas, M., Nazir, T., Shatanawi, W. and Mustafa, Z., Fixed and related fixed point theorems for three maps in G-metric spaces, Hacet. J. Math. Stat., 41 (2012), No. 2, 291-306

[29] Abbas, M., Nazir, T. and Radenović, S., Common fixed point of generalized weakly contractive maps in partially ordered G-metric spaces, Appl. Math. Comput., 218 (2012), No. 18, 9383-9395

[30] Abbas, M., Nazir, T. and Vetro, P., Common fixed point results for three maps in G-metric spaces, Filomat, 25 (2011), No. 4, 1-17

[31] Akram, M., Nosheen, Some fixed point theorems of a-type contractions in g-metric space, Inter. J. Pure Appl. Math., 79 (2012) No. 2, 219-233

[32] Aydi, H., Postolache, M. and Shatanawi, W., Coupled fixed point results for $(\Psi, \Phi)$-weakly contractive mappings in ordered G-metric spaces, Comput. Math. Appl., 63 (2012), No. 1, 298-309

[33] Aydi, H., Shatanawi, W. and Vetro, C., On generalized weakly G-contraction mapping in G-metric spaces, Comput. Math. Appl., 62 (2011), No. 11, $4222-4229$

[34] Aydi, H., Damjanović Bosko, B., Samet, B. and Shatanawi, W., Coupled fixed point theorems for nonlinear contractions in partially ordered G-metric spaces, Math. Comput. Model., 54 (2011), No. 9-10, 2443-2450

Received: 16.11.2012; In revised form: 01.01.2013; Accepted: 24.01.2013

2010 Mathematics Subject Classification. 47H10; 54H25.

Key words and phrases. Distance space, CF-distance space, F-distance space, b-metric space, b-quaimetric space, associate metric to a F-distance, symmetric space, Cauchy sequence, quasinorm, fixed point. 
[35] Beg, I., Butt, A. R. and Radojević, S., The contraction principle for set valued mappings on a metric space with a graph, Comput. Math. Appl., 60 (2010), No. 5, 1214-1219

[36] Choudhury, B. S. and Maity, P., Coupled fixed point results in generalized metric spaces, Math. Comput. Model., 54 (2011), No. 1-2, 73-79

[37] Ding, H.-S. and Karapinar, E., A note on some coupled fixed-point theorems on G-metric spaces, J. Ineq. Appl., 2012, art. no. 170

[38] Gajić, Lj. and Stojaković, M., On Ćirić generalization of mappings with a contractive iterate at a point in G-metric spaces, Appl. Math. Comput., 219 (2012), No. 1, 435-441

[39] Gajić, L. and Lozanov-Crvenković, Z., A fixed point result for mappings with contractive iterate at a point in G-metric spaces, Filomat, 25 (2011), No. 2, 53-58

[40] Gajić, L. and Lozanov-Crvenković, Z., On mappings with contractive iterate at a point in generalized metric spaces, Fixed Point Theory Appl., 2010, art. no. 458086

[41] Gholizadeh, L., Saadati, R., Shatanawi, W. and Vaezpour, S. M., Contractive mapping in generalized, ordered metric spaces with application in integral equations, Math. Probl. Eng., 2011, art. no. 380784

[42] Gu, F. and Ye, H., Common fixed point theorems of altman integral type mappings in G-metric spaces, Abstr. Appl. Anal., 2012, art. no. 630457

[43] Ilić, D., Pavlović, V. and Rakočević, V., Some new extensions of Banach's contraction principle to partial metric space, Appl. Math. Lett., 24 (2011), No. 8, 1326-1330

[44] Jleli, M. and Samet, B., Remarks on G-metric spaces and fixed point theorems, Fixed Point Theory Appl., 2012, 2012:210

[45] Kaewcharoen, A., Common fixed point theorems for contractive mappings satisfying $\Phi$-maps in G-metric spaces, Banach J. Math. Anal., 6 (2012), No. $1,101-111$

[46] Kaewcharoen, A. and Kaewkhao, A., Common fixed points for single-valued and multi-valued mappings in G-metric spaces, Int. J. Math. Anal., 5 (2011), No. 33-36, 1775-1790

[47] Khandaqji, M., Al-Sharif, S. and Al-Khaleel, M., Property P and some fixed point results on $(\Psi, \Phi)$-weakly contractive G-metric spaces, Int. J. Math. Math. Sc., 2012, art. no. 675094

[48] Kumar, M., Compatible maps in G-metric spaces, Int. J. Math. (Ruse), 6 (2012), No. 29-32, 1415-1421

[49] Luong, N. V. and Thuan, N. X., Coupled fixed point theorems in partially ordered G-metric spaces, Math. Comput. Model., 55 (2012), No. 3-4, 1601-1609

[50] Mohanta, S. K., Some fixed point theorems on G-expansive mappings, Kyungpook Math. J., 52 (2012) No. 2, 155-165

[51] Mohanta, S. K., Some fixed point theorems in G-metric spaces, An. Ştiinţ. Univ. "Ovidius" Constanţa Ser. Mat., 20 (2012), No. 1, 285-306

[52] Mohiuddine, S. A. and Alotaibi, A., On coupled fixed point theorems for nonlinear contractions in partially ordered G-metric spaces, Abstr. Appl. Anal., 2012, art. no. 897198

[53] Mustafa, Z., A new structure for generalized metric spaces with applications to fixed point theory, Ph. Dthesis, University of Newcastle, Callaghan, Australia, 2005

[54] Mustafa, Z. and Sims, B., A new approach to generalized metric spaces, J. Nonlinear Convex Analysis, 7 (2006), No. 2, 289-297

[55] Mustafa, Z., Some new common fixed point theorems under strict contractive conditions in G-metric spaces, J. Appl. Math., 2012, art. no. 248937

[56] Mustafa, Z., Common fixed points of weakly compatible mappings in G-metric spaces, Appl. Math. Sci., 6 (2012) No. 89-92, 4589-4600

[57] Mustafa, Z., Mixed g-monotone property and quadruple fixed point theorems in partially ordered $G$-metric spaces using $(\varphi-\psi)$ contractions, Fixed Point Theory Appl., 2012, 2012:199

[58] Mustafa, Z., Shatanawi, W. and Bataineh, M., Existence of fixed point results in G-metric spaces, Int. J. Math. Math. Sc., 2009, art. no. 283028

[59] Mustafa, Z. and Sims, B., Fixed point theorems for contractive mappings in complete G-metric spaces, Fixed Point Theory Appl., 2009, art. no. 917175

[60] Mustafa, Z., Obiedat, H. and Awawdeh, F., Some fixed point theorem for mapping on complete G-metric spaces, Fixed Point Theory Appl., 2008, art. no. 189870

[61] Mustafa, Z., Aydi, H. and Karapinar, E., On common fixed points in G-metric spaces using (E.A) property, Comput. Math. Appl., 64 (2012), No. 6, 1944-1956

[62] Mustafa, Z., Khandagji, M. and Shatanawi, W., Fixed point results on complete G-metric spaces, Studia Sci. Math. Hungar., 48 (2011), No. 3 , 304-319

[63] Nashine, H. K., Kadelburg, Z., Pathak, R. P. and Radenović, S., Coincidence and fixed point results in ordered G-metric spaces, Math. Comput. Model.,57 (2013) No. 3-4, 701-709

[64] Nashine, H. K., Golubović, Z. and Kadelburg, Z., Nonlinear cyclic weak contractions in G-metric spaces and applications to boundary value problems, Fixed Point Theory Appl., 2012, 2012:227

[65] Petruşel, A., Rus, I. A. and Şerban, M. A., Fixed points for operators on generalized metric spaces, Cubo, 10 (2008), No. 4, 45-66

[66] Popa, V. and Patriciu, A.-M., A general fixed point theorem for mappings satisfying an $\Phi$-implicit relation in complete G-metric spaces, Gazi Univ. J. Sci.,25 (2012), No. 2, 403-408

[67] Saadati, R., Vaezpour, S. M., Vetro, P. and Rhoades, B. E., Fixed point theorems in generalized partially ordered G-metric spaces, Math. Comput. Model., 52 (2010), No. 5-6, 797-801

[68] Samet, B., Vetro, C. and Vetro, F., Remarks on G-Metric Spaces, Int. J. Anal., Volume 2013, Article ID 917158, 6 pages http://dx.doi.org/10.1155/2013/917158

[69] Shatanawi, W., Some fixed point theorems in ordered G-metric spaces and applications, Abstr. Appl. Anal., 2011, art. no. 126205

[70] Shatanawi, W., Fixed point theory for contractive mappings satisfying $\Phi$-maps in G-metric spaces, Fixed Point Theory Appl., 2010, art. no. 181650

[71] Shatanawi, W. and Abbas, M., Some fixed point results for multi valued mappings in ordered G-metric spaces, Gazi Univ. J. Sci., 25 (2012), No. 2, 385-392

[72] Shatanawi, W. and Postolache, M., Some fixed-point results for a G-weak contraction in G-metric spaces, Abstr. Appl. Anal., 2012, art. no. 815870

[73] Ye, H. and Gu, F., Common fixed point theorems for a class of twice power type contraction maps in G-metric spaces, Abstr. Appl. Anal., 2012, art. no. 736214

[74] Ahmed, M. A., Some fixed point theorems for multivalued mappings in dislocated quasi-metric spaces, Demonstratio Math., 45 (2012), No. 1, 155-160

[75] Akkouchi, M., Common fixed point theorems for two selfmappings of a b-metric space under an implicit relation, Hacet. J. Math. Stat., 40 (2011), No. 6, 805-810

[76] Aydi, H., Bota, M.-F., Karapinar, E. and Moradi, S. A., Common fixed point for weak $\Phi$-contractions on b-metric spaces, Fixed Point Theory, 13 (2012), No. 2, 337-346

[77] Boriceanu, M., Bota, M. and Petruşel, A., Multivalued fractals in b-metric spaces, Cent. Eur. J. Math., 8 (2010), No. 2, 367-377

[78] Bota, M., Molnar, A. and Varga, C., On Ekeland's variational principle in b-metric spaces, Fixed Point Theory, 12 (2011), No. 1, 21-28

[79] Ćirić, L., Semi-continuous mappings and fixed point theorems in quasi metric spaces, Publ. Math. Debrecen, 54 (1999), No. 3-4, 251-261

[80] Hussain, N. and Shah, M. H., KKM mappings in cone b-metric spaces, Comput. Math. Appl., 62 (2011),No. 4, 1677-1684

[81] Kikina, L. and Kikina, K., Two fixed point theorems on a class of generalized quazi-metric spaces, J. Comput. Anal. Appl, 14 (2012), No. 5, 950-957 
[82] Künzi, H.-P. A. and Olela Otafudu, O., Q-hyperconvexity in quasipseudometric spaces and fixed point theorems, J. Funct. Spaces Appl., 2012, art. no. 765903

[83] Latif, A. and Al-Mezel, S. A., Fixed point results in quasimetric spaces, Fixed Point Theory Appl., 2011, art. no. 178306

[84] Miheț, D. and Zaharia, C., Probabilistic (quasi)metric versions for a stability result of Baker, Abstr. Appl. Anal., 2012, art. no. 269701

[85] Olatinwo, M. O., Some results on multi-valued weakly Jungck mappings in b-metric space, Cent. Eur. J. Math., 6 (2008), No. 4, 610-621

[86] Pant, B. D. and Chauhan, S., Common fixed point theorems for occasionally weakly compatible mappings in Menger probabilistic quasi-metric spaces, Adv. Nonlinear Var. Inequal., 14 (2011), 2, 55-63

[87] Pepo, B., Fixed points for contractive mappings of third order in pseudo-quasimetric spaces, Indag. Math. (N.S.), 1 (1990), No. 4, 473-481

[88] Prasad, B., Singh, B. and Sahni, R., Common fixed point theorems with integral inequality, Appl. Math. Sci., 4 (2010), No. 45-48, 2369-2377

[89] Prasad, B., Singh, B. and Sahni, R., Some approximate fixed point theorems, Inter. J. Math. Anal., 3 (2009), No. 5-8, 203-210

[90] Romaguera, S., Marin, J. and Tirado, P., Q-functions on quasimetric spaces and fixed points for multivalued maps, Fixed Point Theory Appl., 2011, art. no. 603861

[91] Sedghi, S., Zikić-Dosenović, T. and Shobe, N., Common fixed point theorems in Menger probabilistic quasimetric spaces, Fixed Point Theory Appl., 2009, art. no. 546273

[92] Shah, M. H. and Hussain, N., Nonlinear contractions in partially ordered quasi b-metric spaces, Commun. Korean Math. Soc., 27 (2012), No. 1, $117-128$

[93] Singh, S. L. and Prasad, B., Some coincidence theorems and stability of iterative procedures, Comput. Math. Appl., 55 (2008), No. 11, 2512-2520

Department of Mathematics And Computer SCiEnCE

NORTH UNIVERSITY OF BAIA MARE

VICTORIEI 76, 430072 BAIA MARE ROMANIA

E-mail address: vberinde@ubm.ro; vasile_berinde@yahoo.com

DEPARTMENT OF MATHEMATICS

TiRASPOL STATE UNIVERSITY CHIŞINĂU

REPUBLIC OF MOLDOVA

E-mail address: mmchoban@gmail.com 